\title{
Summer management of sheep on summer-wet hill country: insights into decisions made by an "expert" farmer
}

\author{
D.I. GRAY, J.I. REID, P.D. KEMP, I.M. BROOKES, D. HORNE, P.R. KENYON, C. MATTHEW, \\ S.T. MORRIS and I. VALENTINE \\ College of Sciences, Massey University, PB 11222,Palmerston North
}

d.i.gray@massey.ac.nz

\begin{abstract}
Although summer is a critical season for sheep production on summer-wet hill country, little is known about how high-performing farmers manage livestock and pastures during this period. If their practices could be captured and disseminated, it would provide the opportunity for other farmers to increase productivity. The decisions made by a high-performing summer-wet hill-country farmer over summer were investigated using a single-case study design.

This study highlights the relative complexity of summer management on hill country. Farmers must consider key strategic decisions such as when to wean, when to sell, what to sell, how many to sell, where to sell and at what
\end{abstract} weight. In this study, the answers to these questions were found to be a function of the conditions (summerwet versus summer-dry) under which one farms and the amount of finishing country one has. Under summerwet conditions, the need to control pasture quality dictates important strate gic decisions. To control pasture quality, the case farmer runs a high stocking rate (SR), high performance, later lambing system with a low sheep:cattle ratio. This system, particularly with a low proportion of finishing country, is not conducive to lamb finishing and a store policy is a more profitable alternative. As such, the case farmer's focus over summer is on ensuring the potential for high ovulation and conception rates in his ewes and ewe hoggets rather than lamb finishing. This is achieved by ensuring his ewes are in good condition ( 2.7 condition score $(\mathrm{CS})$ ) with adequate feed $(1400 \mathrm{~kg}$ dry matter (DM)/ha) at flushing and his ewe hoggets reach $41 \mathrm{~kg}$ live weight (LW) by May 1st. These nonnegotiable targets are central to the farmer's consistent high performance. Minimisation of the distribution of LW (or CS) about the mean of different sheep classes through preferential feeding of younger, lighter and thinner stock was also found to be a critical element.

To achieve high lamb growth rates, low priority stock and older finishing cattle were used to ensure pastures remained actively growing, of high quality and with low levels of infective larvae. A late weaning date and a high proportion of cattle and older stock were also important in maintaining pasture quality on summer-wet hill country. A critical feature of summer grazing management is area allocation and the use of post-grazing residuals to achieve animal performance targets. Pasture monitoring, microbudgeting and the use of this information in conjunction with market related data, to help decide the appropriate timing of stock sales was central to coping with uncertainty and achieving pasture and animal targets.

Keywords: farmer decision making, grazing management, sheep productivity

\section{Introduction}

Decisions made by hill country farmers over summer can impact substantially on sheep productivity (Geenty 1997). Because the majority of sheep sales are made during this period, farm financial performance is greatly influenced by the associated feeding and marketing decisions. Ewe LW at tupping and the amount of feed taken into winter, key determinants of next season's lamb crop, are also influenced by decisions made over summer. Despite its importance, little is known about the summer management practices of hill country farmers. Some farmers are particularly good at managing this period and if their management practices could be captured and passed onto others, large gains in farm productivity could eventuate. This paper reports on the decisions made by a high-performing summer-wet hill country farmer over summer that were critical for achieving high levels of sheep productivity on his farm.

\section{Materials and methods}

A single-case study design (Yin 1993) was used to investigate the management practices of a highperforming summer-wet hill-country farmer. Local farmers and consultants were used to select the farmer and semi-structured interviews and field observations (Patton 1990) were undertaken monthly to collect data on his decisions over two years. At the start of each planning period (summer was defined as the period from weaning (10 - 15th January) until the start of flushing (10th April)), the farmer was asked to describe his feed planning process, and the structure of the plan derived from this. Monthly interviews were then used to collect information about the implementation of the plan until its completion. Data was collected on the famer's monitoring process and the control decisions he made in response to uncertainty in the environment. The reasons behind the farmer's decisions were also collected. To triangulate 
Table 1 A comparison of the case farmer's physical and financial performance to district data ${ }^{1}$ for the $2001 / 2002$ year.

\begin{tabular}{lccc}
\hline Performance measure & Case farm & District average & Top 10\% \\
\hline Net production/ha $(\mathrm{kg} \mathrm{CW})$ & 304 & 243 & 290 \\
Lambing \% & $153.4 \%$ & $128.6 \%$ & $133 \%$ \\
Wool/SSU (kg/SSU) & 5.1 & 5.4 & 5.5 \\
Wool/ha (kg/ha) & 56 & 55 & 67 \\
Stock units/ha & 11.1 & 10.3 & 12.1 \\
Revenue/sheep SU & $\$ 86.06$ & $\$ 81.78$ & $\$ 89.15$ \\
Revenue/cattle SU & $\$ 116.25$ & $\$ 73.60$ & $\$ 117.46$ \\
Gross farm revenue/SU & $\$ 98.97$ & $\$ 80.68$ & $\$ 96.13$ \\
Gross farm revenue/ha & $\$ 1,094$ & $\$ 833$ & $\$ 1,159$ \\
Standard expenses/SU & $\$ 32.03$ & $\$ 43.12$ & $\$ 37.24$ \\
Standard expenses/ha & $\$ 354$ & $\$ 445$ & $\$ 449$ \\
Economic farm surplus/SU & $\$ 63.18$ & $\$ 33.45$ & $\$ 52.76$ \\
Economic farm surplus/ha & $\$ 698$ & $\$ 345$ & $\$ 636$ \\
Return on capital & $14.6 \%$ & $7.9 \%$ & $9.9 \%$ \\
\hline${ }^{2}$ Data obtained from Baker \& Associate's Farm Analysis Bureau. & & \\
${ }^{2}$ Wool/SSU multiplied by SR. & & & \\
\hline
\end{tabular}

information provided in the interviews, secondary data (pasture mass, pasture height, LW, CS, stock sales etc.) was collected where possible. Interviews were transcribed verbatim and then analysed using qualitative data analysis techniques (Dey 1993). The farmer's management practices were modelled, verified with the farmer and then compared with the literature.

\section{Results and discussion}

To make sense of a case study, key elements of its context must be provided (Yin 1993). The case farm is 657 ha effective comprising 30 ha flats, 50 ha of rolling, but cultivatable land, 120 ha of uncultivated easy and 457 ha of steep hill country. It is classified as a summer-wet semi-finishing farm because of its steeper contour and average rainfall of $1500 \mathrm{~mm}$ per annum. The farm has Olsen phosphorus levels of $15-25 \mu \mathrm{g} / \mathrm{ml}$ with a soil $\mathrm{pH}$ of 5.4-5.9 and is estimated to grow around $9500 \mathrm{~kg}$ $\mathrm{DM} / \mathrm{ha} / \mathrm{yr}$. Physical and financial performance for the year prior to the study is summarised in Table 1. In year one of the study, the farm wintered 3775 ewes, 1215 hoggets, $203 \mathrm{R} 1 \mathrm{yr}$ and $365 \mathrm{R} 2 \mathrm{yr}$ bulls at a stocking rate of $11.8 \mathrm{su} / \mathrm{ha}$ and a sheep to cattle ratio of $61: 39$.

The farmer's management of his sheep over summer must also be understood from the perspective of his strategy. He has designed a high SR (11.8 SU/ha), high performance (140-150\% lambing), later lambing (20th September) sheep system to best match feed demand with spring pasture growth to control pasture quality. To increase spring feed demand, the hoggets are also lambed in early-October. The farmer has adopted a store lamb policy because of his later lambing date and lack of finishing country. During summer, the older cattle are grown at between $0.8-1.0 \mathrm{~kg} \mathrm{hd} /$ day with the $\mathrm{R} 3 \mathrm{yr}$ and R2yr bulls sold by the end of January and March respectively at $560-580 \mathrm{~kg} \mathrm{LW}$. Three hundred yearling bulls are bought in spring to help control pasture quality and during summer, these bulls are grown at $0.2 \mathrm{~kg} / \mathrm{hd} /$ day and used to maintain pasture quality.

Key strategic decisions in relation to sheep productivity over summer include when to wean, when to sell, how many to sell and where to sell (store or works market), what rate of LW gain and what target LW for sale lambs. The choice of weaning date is primarily driven by the need to maintain pasture quality. Weaning date (10th 15 th January) is delayed to maintain grazing pressure until the sward returns to a vegetative state, a management practice advocated by Bircham (1983).

The various decisions associated with lamb selling are a function of the farmer's strategy. The farmer has decided that because his farm is summer-wet and has limited finishing country, it is more profitable to run a high SR high performance, later lambing, store lamb system than a lower SR, lower performance, earlier lambing, lamb finishing system. A key driver of this strategy was the need to control pasture quality over spring. Bircham (1983) also advocated the adoption of later lambing and more prolific sheep breeds to better match feed demand with supply on summer-wet hill country.

The farmer sells lambs store rather than to the works because he normally receives a higher price $(\$ 1-\$ 2 / \mathrm{hd})$ and labour and organisational costs are lower. The strategic decisions about lamb selling (when to sell, how many to sell and at what weight) are a function of feed supply and demand. Feed available for lambs over summer is a function of; SR, the intake requirements of capital stock (ewe lambs, two tooths, ewes, replacement R1yr and R2yr bulls), cull ewe and cattle sale policies, and the required increase in pasture cover between weaning and flushing. The choice of a high $(11.8 \mathrm{SU} /$ ha) SR system limits the availability of summer feed relative to a more lowly (10 SU/ha) stocked system. The 
Figure 1 Methods used to optimise non-replacement lamb LW gain over summer.

\begin{tabular}{|c|c|c|c|}
\hline & \multicolumn{2}{|c|}{$\begin{array}{l}\text { Optimise non-replacement lamb } \\
\text { liveweight gain over summer }\end{array}$} & \\
\hline $\begin{array}{l}\text { Ensure adequate } \\
\text { feed is available }\end{array}$ & $\begin{array}{l}\text { Ensure high quality } \\
\text { feed is available }\end{array}$ & $\begin{array}{l}\text { Minimise internal } \\
\text { parasite problems }\end{array}$ & $\begin{array}{l}\text { Ensure lambs have the } \\
\text { potential to grow } \\
\text { quickly over summer }\end{array}$ \\
\hline $\begin{array}{ll}\text { - } & \text { stock at } 20-30 \\
& \text { lambs/ha } \\
\text { - } & \text { pre-grazing pasture } \\
& \text { cover of } 6.0 \mathrm{~cm} \\
& (1500 \mathrm{~kg} \mathrm{DM} / \mathrm{ha}) \\
\text { - } & \text { post-grazing pasture } \\
& \text { cover of } 4.0 \mathrm{~cm}(1200 \\
& \mathrm{kg} \mathrm{DM} / \mathrm{ha}) \\
\text { - } & \text { two weeks per block }\end{array}$ & $\begin{array}{l}\text { - Graze the best } \\
\text { paddocks on the sheep } \\
\text { block } \\
\text { - Use ewes and yearling } \\
\text { cattle to prepare lamb } \\
\text { feed (RDM = } 1000 \text { - } \\
1100 \mathrm{~kg} \mathrm{DM} / \mathrm{ha}) \\
\text { - Prepare feed ahead of } \\
\text { lambs with older cattle } \\
(\mathrm{RDM}=1200-1300 \\
\mathrm{kg} \mathrm{DM} / \mathrm{ha})\end{array}$ & $\begin{array}{l}\text { - Sell bulk of lambs at } \\
\text { weaning } \\
\text { - Only graze a paddock } \\
\text { once with lambs over } \\
\text { summer } \\
\text { - Drench every four } \\
\text { weeks } \\
\text { - Integration of cattle }\end{array}$ & $\begin{array}{l}\text { - Sell lambs }<25.0 \mathrm{~kg} \\
\text { LW at weaning }\end{array}$ \\
\hline
\end{tabular}

farmer has set high LW and CS targets for the capital sheep stock in order to ensure a high lambing percentage. This again limits the feed available for lamb finishing relative to lower performing sheep systems. Similarly, the feed required for the R2yr and R3yr bulls to reach their target sale weights $(560-580 \mathrm{~kg} \mathrm{LW})$ limits how much feed is available for sale lambs. Cull ewes (700) rather than lambs are retained post-weaning because they improve pasture quality, and shed less inter nal parasites.

The above constraints limit the amount of feed the farmer has available (on average) over the summer for sale lambs. He must then decide how many lambs he should run for this pool of feed. This choice is based on the maximum LW gain lambs can achieve on this country, which is normally around $100 \mathrm{~g} / \mathrm{hd} /$ day. At this level of performance, the pool of available feed can carry 1000 lambs (20-25\% of total sale lambs) from weaning until the end of March.

The farmer must also decide which lambs to retain and which to sell at weaning. At weaning (10th-15th January), the 5200 lambs from the ewe flock average $27-28 \mathrm{~kg} \mathrm{LW}$ at an average a ge of 113 days. There are also around 700 ewe hogget lambs that average $20 \mathrm{~kg}$ LW at an average age of 97 days. The farmer retains a medium (25-30 kg LW) line of 1000 lambs because he believes that lighter lambs do not perform well postweaning and heavier lambs ( $>35 \mathrm{~kg} \mathrm{LW})$ are discounted on the store market. As such the light $(<25 \mathrm{~kg} \mathrm{LW})$ and heavy lambs $(>30 \mathrm{~kg} \mathrm{LW})$ are sold at weaning and make up the bulk (75-80\%) of lamb sales. The medium line of
$1000 \mathrm{lambs}$ are grown at $70-120 \mathrm{~g} / \mathrm{hd} /$ day from midJanuary to March and sold at 30-35 kg LW. Fraser \& Saville (2000) found that heavier lambs ( 25 and $30 \mathrm{~kg}$ LW) grow faster than lighter lambs (20 kg LW) postweaning, but these results were only statistically significant in two out of five years. This trend was most consistent for ram lambs, twin lambs reared as twins and on improved as opposed to resident pastures.

Once strategic decisions have been made about lamb sales, tactical and operational decisions are important for the implementation of the strategy. To meet the LW gain targets set by the farmer (Figure 1), the retained lambs are given the best paddocks on the sheep area and stocked at 20-30 lambs/ha on blocks for two-weekly intervals. The farmer aims for pre- and post-grazing pasture cover levels (based on a winter pasture cover calibration) of $1500 \mathrm{~kg} \mathrm{DM} / \mathrm{ha}$ and $1200 \mathrm{~kg} \mathrm{DM} / \mathrm{ha}$, respectivel y. These pasture cover levels equate to a pasture height range of $6 \mathrm{~cm}$ down to $4 \mathrm{~cm}$. Allowing for differences between winter and summer pasture cover calibrations, these pasture heights are similar to the pasture cover levels of $2000 \mathrm{~kg} \mathrm{DM} / \mathrm{ha}$ to $1200 \mathrm{~kg} \mathrm{DM} / \mathrm{ha}$ recommended by Rattray et al . (1987) for ac hieving high rates of LW gain in lambs.

Ewes and cattle are used to prepare lamb feed (see later). The two-week grazing interval allows the lambs to be stocked more lightly than if a shorter interval was used, thereby providing greater opportunity for selective grazing. Inability to prepare a sufficient area of lamb feed prevents the use of a longer grazing interval. Internal 
Figure 2 Methods used to optimise the potential for high ewe ovulation and conception rates.

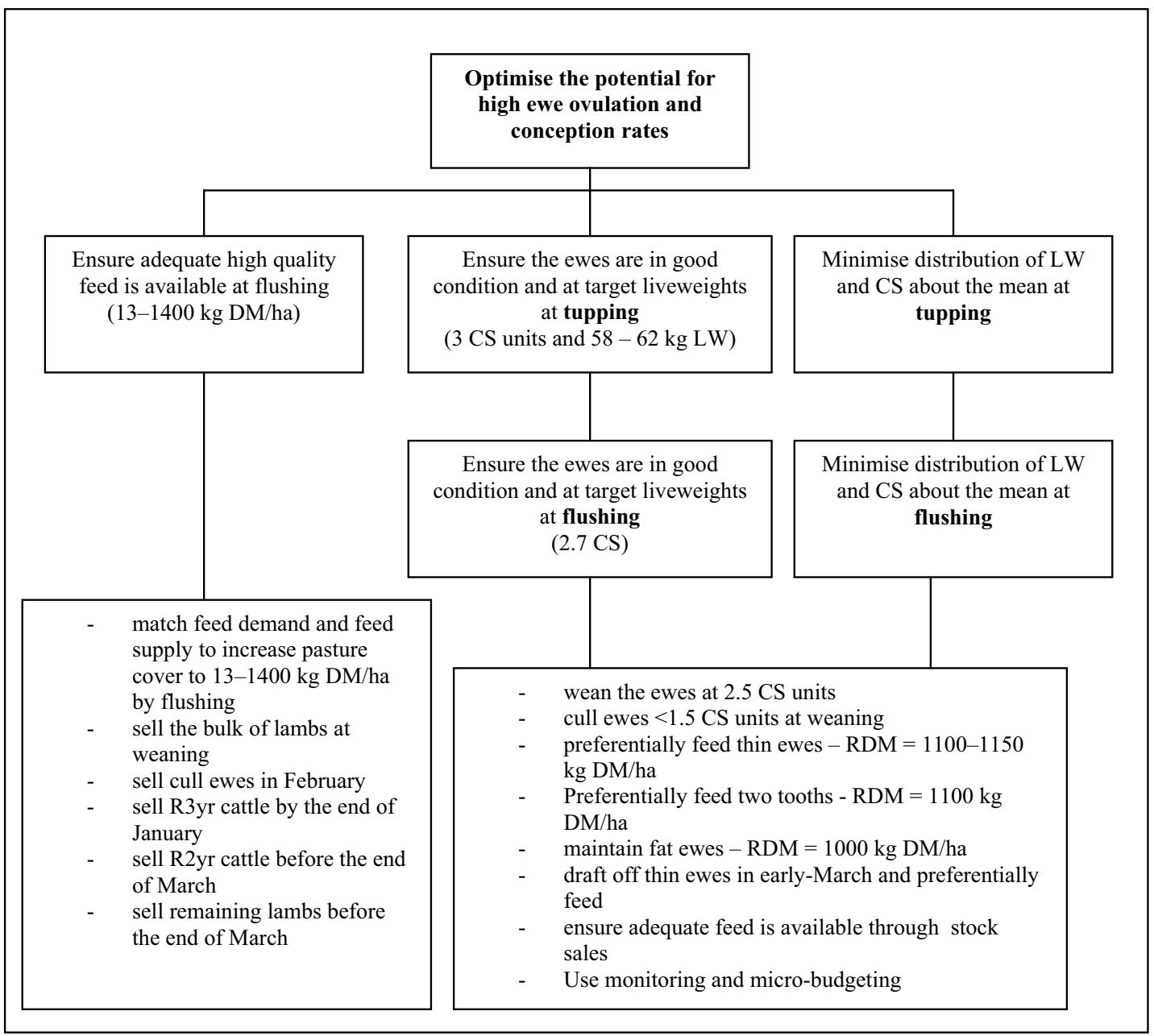

parasite problems are minimised by: selling the bulk of lambs at weaning, drenching four-weekly, avoiding grazing the same paddock twice with lambs and integrating cattle.

Information on; pasture cover levels, weather forecasts, store and works prices, market reports, the exchange rate, price forecasts by agents and weather and feed information about other districts and regions is used to help make stock selling decisions. Micro-budgeting techniques (Gray 2003) are used to estimate the likely feed surplus or deficit at fortnightly intervals (associated with the next lamb shift). Tactical decisions about what to sell, when to sell, what weight to sell at and how many to sell ar e based on the farmer's expectations of the amount of feed he will have available in the next two weeks, and the margin he can expect to make from different stock classes using this feed.

Because the focus of the farmer's strategy is on maximising the production of store lambs, decisions made in summer are critical because of their impact on next season's lambing percenta ge. To optimise the potential for high ewe ovulation and conception rates, (Figure 2) the farmer ensures that the average pasture cover on his sheep country is $1400 \mathrm{~kg} \mathrm{DM} / \mathrm{ha}$ at the end of summer (start of flushing). Research has shown that ewe ovulation rates increase in response to greater pasture mass over flushing (Smith 1991). To ensure his ewes are in suita ble condition at mating, the farmer aims to have them in good condition (2.7 CS) at the start of flushing (10th April) with target LWs of $61 \mathrm{~kg}$ and $57 \mathrm{~kg}$ for mix ed age and two tooth ewes respectively (Figure 2). He wants the composite ewes at CS 3 at tupping (20th April), but does not want them to exceed $62 \mathrm{~kg} \mathrm{LW}$. This is because at $150 \%$ lambing, he believes that the gains from heavier ewes with higher ovulation rates do not out-weigh the cost in terms of reduced SR, particularly because of the marked increase in triplet-bearing ewes that have high lamb losses on hill country. The recent work of Rutherford 
Figure 3 Methods used to optimise the potential for high hogget ovulation and conception rates.

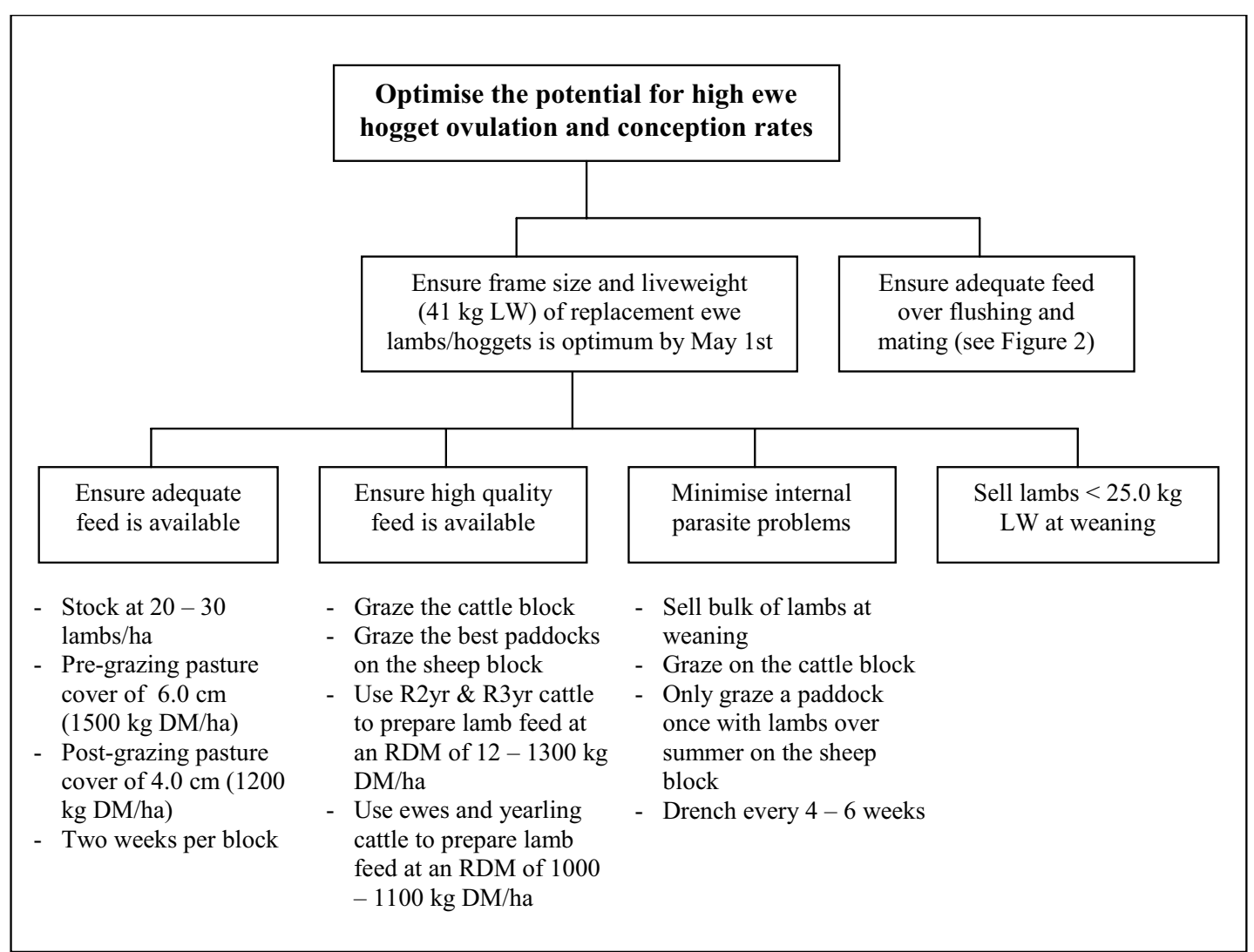

et al. (2003) with Coopworths supports this view. The farmer also wants to minimise the variation in LW (or CS) about the mean.

The above goals are achieved by weaning the ewes at $2.5 \mathrm{CS}$ (to minimise ewe feed requirements over summer (Thompson et al. (1990)), culling thin ewes (<1.5 CS) and preferentially feeding the two-tooths (residual DM $(\mathrm{RDM})=1100 \mathrm{~kg} \mathrm{DM} / \mathrm{ha})$ and thinner ewes $(\mathrm{RDM}=$ $1150 \mathrm{~kg} \mathrm{DM} / \mathrm{ha}$ ) over summer (Figure 2). Preferential feeding of ewes over summer will increase ovulation rates, but the response is higher for thin ( 1.35 vs. 1.01 corpora lutea/ewe) as opposed to fat (1.44 vs. 1.21 comora lutea/ewe) ewes, where LW is increased to a similar degree (4-5 kg) (Morton 1992). Rutherford et al. (2003) reported that further increases in ovulation rate above $68 \mathrm{~kg} \mathrm{LW}$ in Coopworth ewes are unlikely and that farmers are better off feeding their lighter ewes. Similarly, Kenyon et al. (2004a) reported that no reproductive advantage was measured above a minimum $\mathrm{CS}$ of $3(62.6 \mathrm{~kg} \mathrm{LW})$ and $2(48.5 \mathrm{~kg} \mathrm{LW})$ at mating for Romney mixed age and two tooth composite ewes respectively. They ad vocated that farmers should manage their ewe flocks to achieve minimum, rather than average CS or LW tar gets.
Stock sales are planned to reduce feed demand over summer so that the farmer's target of $1400 \mathrm{~kg} \mathrm{DM} / \mathrm{ha}$ is met. Analysis of animal intakes found that feed demand was reduced from $40 \mathrm{~kg} \mathrm{DM} /$ ha/day just prior to weaning to $20 \mathrm{~kg} \mathrm{DM} / \mathrm{ha} /$ day in March through the sale of 4600 lambs, 700 cull ewes, 360 R3yr bulls and $200 \mathrm{R} 2 \mathrm{yr}$ bulls. Because of variability in pasture growth, pasture monitoring and micro-budgeting (Gray et al. 2003) are used to adjust the planned pattern of stock sales in order to meet the target of $1400 \mathrm{~kg} \mathrm{DM} / \mathrm{ha}$ and ensure capital stock are fed to requirements. The retention of 700 cull ewes post-weaning allows poor quality pastures to be hard grazed without placing younger and thinner ewes under nutritional stress.

To maximise the production of store lambs, the farmer also aims to optimise the potential for high ewe hogget ovulation and conception rates (Figure 3). This is achieved by ensuring that they reach target fr ame size and LW (41 $\mathrm{kg} \mathrm{LW}$ ) by May 1 st and there is adequate pasture for flushing. In a survey of farmers that lambed hoggets, Kenyon et al. (2004b) reported that for every $1 \mathrm{~kg} \mathrm{LW}$ above $36 \mathrm{~kg}$ at mating, hogget lambing percentage increased 2\%. Similarly McMillan \& Moore (1983) reported that for each extra $1 \mathrm{~kg} \mathrm{LW}$ at hogget mating 
Figure 4 Grazing pattern for cattle blocks used by the ewe lambs.

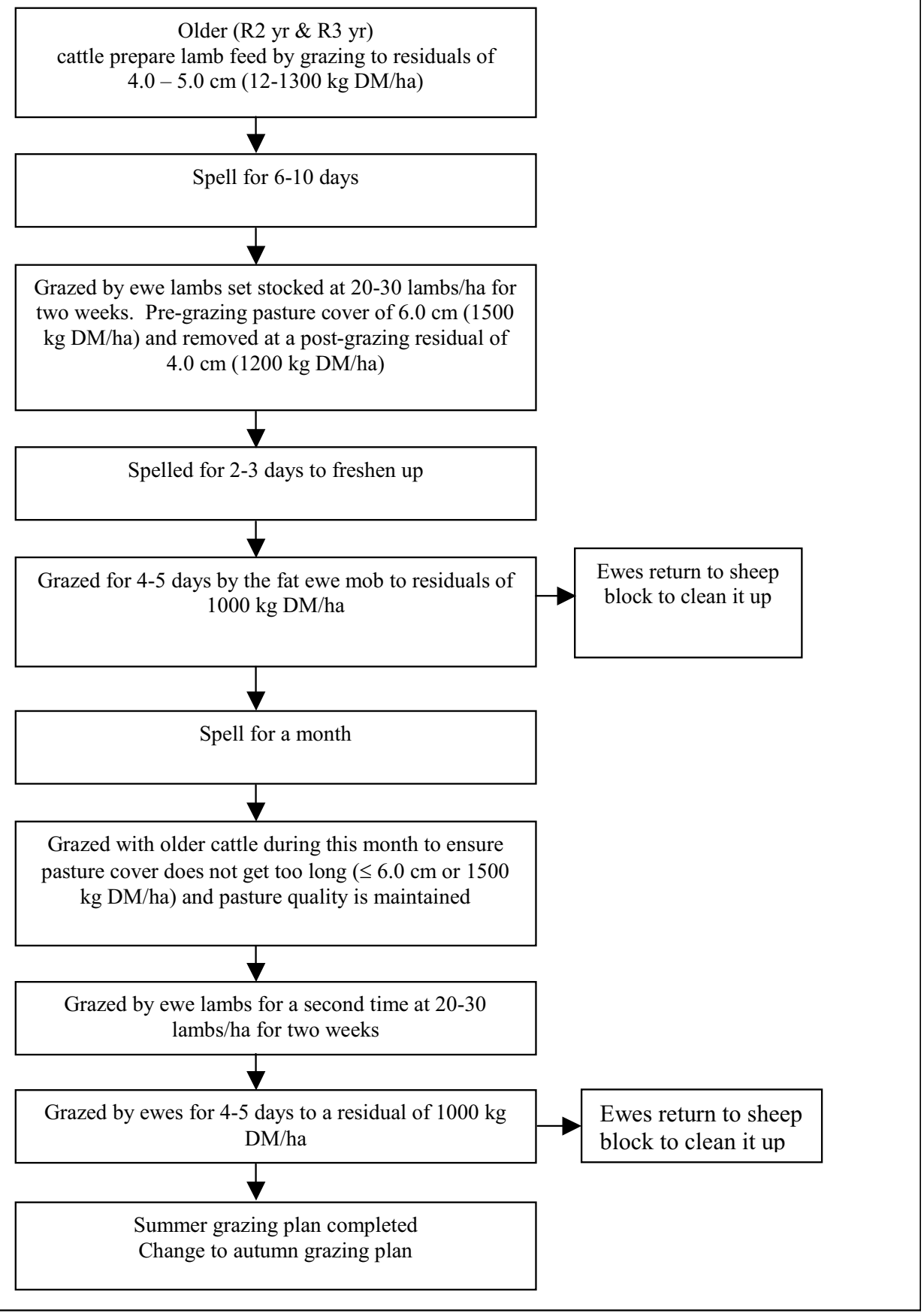

there was a $3.3 \%$ increase in hoggets mated over hoggets joined and a $3.5 \%$ increase in lambs born/ hogget joined. To achieve the target LW at May 1st, light ewe lambs $(<25 \mathrm{~kg} \mathrm{LW})$ are culled at weaning because the farmer believes the heavier lambs grow more quickly (Figure
3). Although Fraser \& Saville (2000) found that in general, heavier lambs grow faster post-weaning, data for ewe lambs showed no significant difference.

To reach target LW by May 1st, the ewe lambs are grown quickly $(100-130 \mathrm{~g} / \mathrm{hd} /$ day $)$ by providing them 
Figure 5 Summer/autumn grazing plan for the ewe lambs.

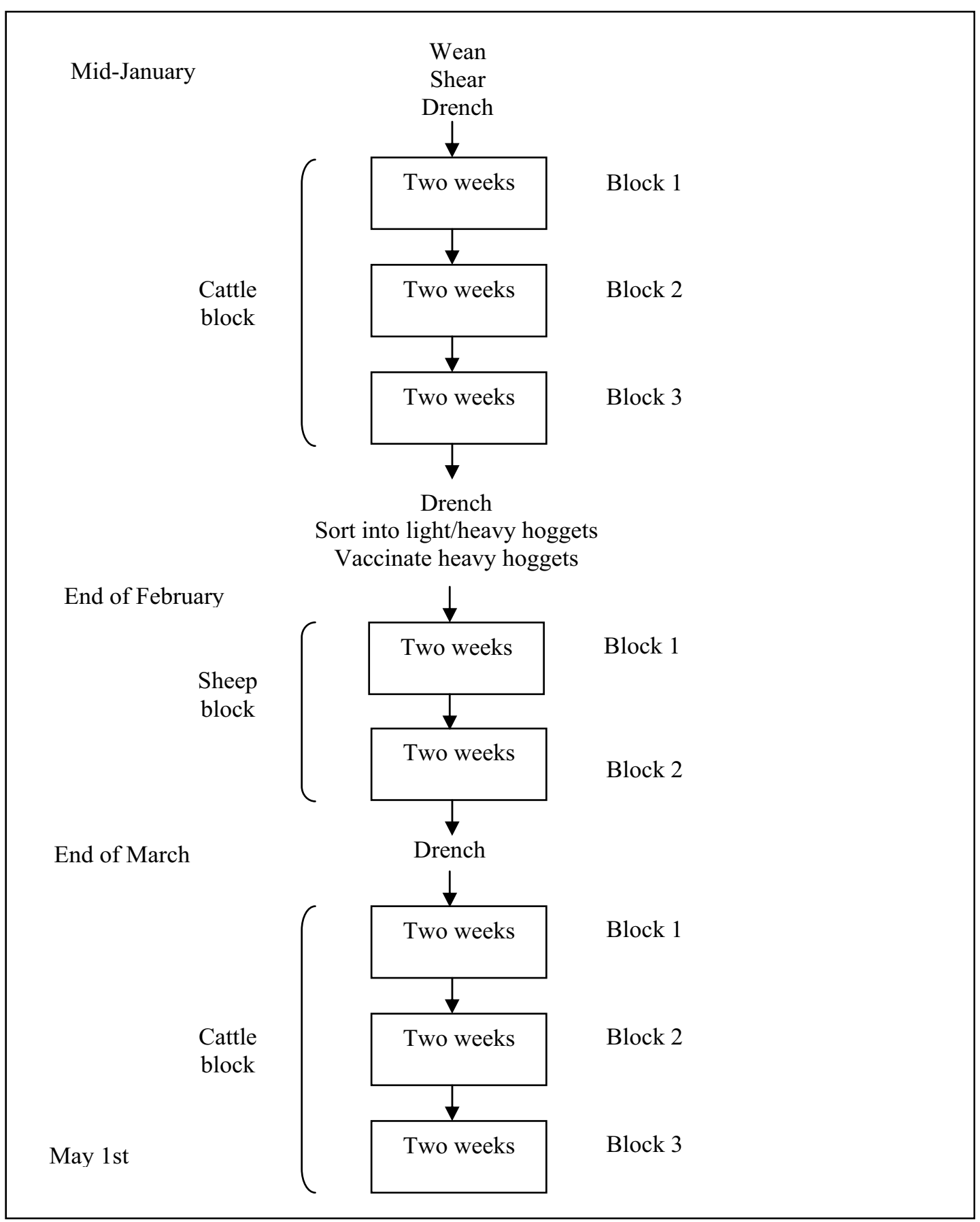

with sufficient high quality pasture and minimising intemal parasite problems (Figure 3). As the highest priority stock on the farm they are weaned onto the cattle block to provide them with the best quality feed. The ewe lambs are stocked at $20-30$ lambs/ha on blocks for two-weekly intervals with pre- and post-grazing pasture cover levels of $6 \mathrm{~cm}(1500 \mathrm{~kg} \mathrm{DM} / \mathrm{ha})$ and $4 \mathrm{~cm}(1200$ $\mathrm{kg} \mathrm{DM} / \mathrm{ha}$ ) respectively (Figures 4 and 5).

Six weeks post-weaning, the ewe lambs are weighed and separated into light $(<35 \mathrm{~kg} \mathrm{LW})$ and heavy $(>35$ 
$\mathrm{kg} \mathrm{LW)} \mathrm{mobs.} \mathrm{The} \mathrm{heavy} \mathrm{mob} \mathrm{is} \mathrm{mated} \mathrm{in} \mathrm{May} \mathrm{and} \mathrm{as}$ such, is vaccinated for Toxioplasmosis and Campylobacter. Kenyon et al. (2004b) reported that the vaccination of mated hoggets improved lambing performance by $5 \%$. Both mobs are then moved to the sheep country where they are grazed to the same residuals, but the heavier mob is given better quality feed. The ewe lambs graze the sheep country for a month whilst the cattle country is spelled. They are drenched at the end of four weeks, before returning to the cattle block for another six weeks (Figures 4 and 5).

Internal parasite problems are minimised through selling the bulk (75-80\%) of sale lambs at weaning, the use of safe pasture, the integration of cattle and a 4-6 weekly drenching program (Figure 4 and 5). Brunsdon \& Vlassoff (1982) reported that an appreciable LW gain advantage $(6.3 \mathrm{~kg})$ could be obtained from the anthelmintic treatment of lambs at weaning if the treatment was accompanied by a move to safe pasture. The gain from such treatment without the use of safe pasture was small (0.8 kg LW). Similarly, Thompson \& Power (1991) reported that grazing cattle ahead of lambs significantly reduces pasture larvae levels and lamb faecal egg counts and increases LW gain compared with grazing ewes ahead. They also found that even under an integrated management system designed to minimise nematode parasitism in lambs, regular anthelmintic drenching significantly increased the LW gains of lambs over summer. Worm burden is further minimised by only grazing a paddock once with lambs over the summer on the farmer's sheep country. Brunsdon \& Vlassoff (1982) stated that if other stock are being used to prepare lamb feed, lambs should not be allowed into such areas because they are the primary source of infective larvae o ver summer.

The final goal the farmer has for the summer, and one that is critical for summer-wet hill country is to ensure that he has actively growing, high quality pastures. Several strategic decisions are important in achieving this goal. The farmer delays weaning until the sward has returned to a vegetative state to maintain pasture quality, a practice advocated by Bircham (1983). He also runs a high ratio of cattle (39\%) to sheep $(61 \%)$, in order to maintain pasture quality, a point stressed by other authors (Rattray et al. 1987; Lambert et al. 2000). A high proportion of older stock is on-hand over summer to help maintain pasture quality. Some $95 \%$ of the cattle stock units on-hand at weaning are R2yr and R3yr bulls. Similarly, 700 cull ewes are retained for a month postweaning instead of lambs to better maintain pasture quality. Cazacar ra \& Petit (1995) demonstrated that older cattle are less selective grazers than younger cattle.

Tactical decisions are also important for maintaining actively growing, high quality pastures over summer. A key feature of the farmer's management is that the sward is grazed to relatively low RDM levels. The farmer uses his winter pasture cover calibration throughout the year, with $4 \mathrm{~cm}$ pasture height equating to $1200 \mathrm{~kg} \mathrm{DM} / \mathrm{ha}$. Low priority stock (ewes and working R2yr cattle) clean up paddocks ( $\mathrm{RDM}=1000-1100 \mathrm{~kg} \mathrm{DM} / \mathrm{ha}$ ) after lambs, and higher priority stock ( $\mathrm{R} 2 \mathrm{yr}$ and $\mathrm{R} 3 \mathrm{yr}$ cattle) prepare pasture ahead of them (RDM $=1200-1300 \mathrm{~kg} \mathrm{DM} / \mathrm{ha})$. Cattle are integrated with sheep to minimise ewe CS loss. Lewis \& Cullen (1973) reported that close grazing $(<5 \mathrm{~cm})$ over summer resulted in both higher quality pastures and higher lamb growth rates when compared to lax ( $>5 \mathrm{~cm}$ ) grazing. Similarly, Smeaton et al. (1984) found that hard grazing over summer resulted in pastures with higher green leaf content at flushing when compared to lax grazing. They also advocated the integration of cattle with sheep to clean up rank pasture in order to minimise ewe bodyweight loss. The importance and need to integrate cattle on hill country has also been stressed by other authors (Rattray et al. 1987; Lambert et al. 2000).

\section{Conclusions}

This study highlights the relative complexity of summer management on hill country. Farmers must consider key strategic decisions such as when to wean, when to sell, what to sell, how many to sell, where to sell and at what weight. In this study, the answers to these questions were found to be a function of the conditions (summerwet vs. summer-dry) under which one farms and the amount of finishing country one has. Under summerwet conditions, the need to control pasture quality dictates important strategic decisions. To control pasture quality, the case farmer runs a high SR, high performance, later lambing system with a low sheep:cattle ratio. This system, particularly with a low proportion of finishing country, is not conducive to lamb finishing and a store policy is a more profitable alternative. As such, the case farmer's focus over summer is on ensuring the potential for high ovulation and conception rates in his ewes and ewe hoggets rather than lamb finishing. This is achieved by ensuring his ewes are in good condition (2.7 CS) with adequate feed ( $1400 \mathrm{~kg} \mathrm{DM} / \mathrm{ha})$ at flushing and his ewe hoggets reach $41 \mathrm{~kg} \mathrm{LW}$ by May 1st. These nonneg otiable targets for are central to the famer's consistent high performance. Minimisation of the distribution of LW (or CS) about the mean of different sheep classes through preferential feeding of younger, lighter and thinner stock was also found to be a critical element.

To ac hieve high lamb growth $r$ ates, low priority stock and older finishing cattle were used to ensure pastures remained actively growing, of high quality and with low levels of infective larvae. A late weaning date, high proportion of cattle and older stock, were also important in maintaining pasture quality on summer-wet hill country. A critical feature of summer grazing management is area 
allocation and the use of post-grazing residuals to achieve animal performance targets. Pasture monitoring, microbudgeting and the use of this information in conjunction with market related data, to help decide the appropriate timing of stock sales was central to coping with uncertainty and achieving pasture and animal targets.

\section{ACKNOWLEDGEMENT}

The group would like to thank our case farmer for his time and effort, and the C. Alma Baker Trust for funding this project.

\section{REFERENCES}

Bircham, J.S. 1983. Pattern of herbage growth during lactation and level of herbage mass at lambing: Their significance to animal production. Proceedings of the New Zealand Grassland Association 45: 177-183.

Brunsdon, R.V.; Vlassoff, A. 1982. Parasite control A revised approach, pp. 53-64. In: Control of Internal Parasites in Sheep. Ed. Ross, A.D. Lincoln College. Canterbury.

Cazacarra, R.F.; Petit, M. 1995. The influence of animal age and sward height on the herbage intake and grazing behaviour of Charolais cattle. Animal Science 61: 497-506.

Dey, I. 1993. Qualitative Data Analysis: A Userfriendly Guide for Social Scientists. Routledge: New York, USA.

Fraser, T. J.; Saville, D. J. 2000. The effect of weaning weight on subsequent lamb growth rates. Proceedings of the New Zealand Grassland Association 62: 75-79.

Geenty, K.G. 1997. A Guide to Improved Lambing Percentage for Farmers and Advisors. The New Zealand Meat Producer Board and Wools of New Zealand. Palmerston North.

Gray, D.I.; Parker, W.J.; Kemp, E.A.; Kemp, P.D.; Brookes, I.M.; Horne, D.; Kenyon, P.R.; Matthew, C.; Morris, S.T.; Reid, J.I.; Valentine, I. 2003. Feed planning-alternative approaches. Proceedings of the New Zealand Grassland Association 65: 211-218.

Gray, D.I.; Reid, J.I.; Kemp, P.D.; Brookes, I.M.; Horne, D.; Kenyon, P.R.; Matthew, C.; Morris, S.T.; Valentine I. 2004. Controlling pasture quality on hill country: Key decisions and techniques. Proceedings of the New Zealand Society of Agronomy 34: 73-82.

Kenyon, P.R.; Morel, P.C.H.; Morris, S.T. 2004a. The effect of individual liveweight and condition scores of ewes at mating on reproductive and scanning performance. New Zealand Veterinary Journal 52: 230-235.

Kenyon, P.R.; Pinchbeck, G.L.; Perkins, N.R.;
Morris, S.T.; West, D.M. 2004b. Identifying factors which maximise the lambing performance of hoggets: A cross sectional study. New Zealand Veterinary Journal 52: 371-377.

Lambert, M.G.; Paine, M.S.; Sheath, G.W.; Webby, R.W.; Litherland, A.J.; Fraser, T.J.; Stevens, D.R. 2000. How do sheep and beef farmers manage pasture quality? Proceedings of the New Zealand Grassland Association 62: 117-121.

Lewis, K.H.C.; Cullen, N.A. 1973. Lamb growth on "long" and "short" grazed pastures of ryegrass or timothy/cocksfoot. Proceedings of the New Zealand Grassland Association 34: 199-204.

McMillan, W.H.; Moore, R.W. 1983. Capitalizing on hogget oestrus. Proceedings of the Sheep and Beef Cattle Society of the New Zealand Veterinary Association Seminar 13: 47-52.

Morton, J.D. 1992. Management of poor quality pastures for maximum animal performance during summer. Proceedings of the New Zealand Grassland Association 54: 85-89.

Patton, M.Q. 1990. Qualitative Evaluation Methods. Sage Publications. Beverley Hills, CA.

Rattray, P.V.; Thompson, K.F.; Hawker, H.; Sumner, R.M.W. 1987. Pastures for sheep production. pp. 89-103. In: Livestock Feeding on Pasture. Ed. Nicol, A. M. New Zealand Society of Animal Production Occasional Publication No. 10.

Rutherford, L.; Nicol, A.M.; Logan, C.M. 2003. Recognising the limits to liveweight-reproduction relationships in ewes. Proceedings of the New Zealand Society of Animal Production 63: 140-143.

Smeaton, D.C.; Wadams, T.K.; Mackisack, B.D.; Winter, R.D.; Miller, C.M. 1984. Spring-summer grazing management on hill country: Effects on ewe performance. Proceedings of the New Zealand Society of Animal Production 44: 117-120.

Smith, J.F. 1991. A review of recent developments on the effect of nutrition on ovulation rate (the flushing effect) with particular reference to research at Ruakura. Proceedings of the New Zealand Society of Animal Production 51: 15-23.

Thompson, K.F.; Sedcole, J.R.; O'Connell, D.; Geenty, K.G.; Sykes, A.R. 1990. Spring and summer pasture feeding and ewe reproduction and wool growth. Proceedings of the New Zealand Grassland Association 52: 123-127.

Thomson, N.A.; Power, M.T. 1991. Effect of grazing management on minimising effects of parasitic nematodes on lamb production. Proceedings of the New Zealand Grassland Association 53: 129-134.

Yin, R.K. 1993. Application of Case Study Research. Sage Publications. London, UK. 